\title{
CHIPRE EN LA CRUZ
}

T os legítimos habitantes de Famagusta, que vivían dentro de sus límites municipales exigen el inmediato regreso a sus hogares, de los que fueron expulsados en 1974, sin mayores retrasos, y llaman al Gobierno, al mundo político y a las organizaciones de Chipre a proceder a todas las indispensables pasos internacionales y a continuar planteado urgentemente la particularidad y prioridad de la solución del caso de Famagusta.

Con un voto aprobado por aclamación en la manifestación contra la ocupación de Famagusta, que se realizó el día sábado.4 de agosto. en Dirinia, los habitantes de la ocupada ciudad de Evágoras llaman también a "Europa, con sus organismos competentes, a jugar un rol protagónico para conseguir el retorno de los habitantes de una ciudad europea y estar a la altura de los principios que integran el ser europeo y los principios europeos".

Declarando que luchan con todos los refugiados por el inalienable derecho del regreso a sus hogares, los famagustinos llaman, igualmente, "a la Organización de las Naciones Unidas a aplicar sus resoluciones y especialmente la resolución 550 de 1984 del Consejo de Seguridad”.

Los famagustinos proclaman que consideran que "el retorno a Famagusta a sus legítimos habitantes creará los condiciones para el progreso y solución al Problema Chipriota” y "paralelamente creará condiciones de colaboración con nuestros compatriotas turcochipriotas en todos los niveles".

"Por todas estas razones, se agrega en el voto aprobado, "proclamamos nuestra irrevocable decisión de continuar, del modo más decisivo, la lucha por el regreso a nuestras casas y nuestras propiedades, y llamamos al resto del pueblo de Chipre a marchar junto a nosotros en este combate".

Durante el transcurso de la manifestación, y antes de la aprobación del voto, se había realizado una concentración en la iglesia de San Modesto en Dirinia y, desde allí, las jóvenes y los jóvenes marcharon sin pancartas ni consignas hasta el Centro Cultural de Famagusta en Dirinia.

Allí tuvo lugar a continuación en el Memorial de Famagustinos Asesinados el responso del Obispo de Constancia y Famagusta, monseñor Basilio, a la que siguió la colocación de coronas y discursos. La manifestación se completó con la aprobación del voto y un programa artístico. 